\title{
THE EFFECT OF CORPORATE CULTURE ON GOOD GOVERNMENT GOVERNANCE, SURVEY OF PROVINCIAL, REGENCY AND CITY GOVERNMENTS IN THE SOUTH SUMATRA REGION.
}

\author{
Irlan Fery ${ }^{1 *}$ \\ *l Lecturer of STIE Rahmaniyah,Jl. Merdeka No.5731 Muba-SUMSEL, Indonesia
}

*Corresponding Author: -

\begin{abstract}
:
The purpose of this study is to determine the effect of Corporate Culture on Good Government Governance. The unit of analysis in this study is the regional government in South Sumatra, Palembang-Indonesia City. The results of the study show that the Corporate Culture has a significant effect on Good Government Governance which has characteristics possessed by someone to produce accurate information. Furthermore, it was found that corporate culture has implications for Good Government Governance.
\end{abstract}

Keywords: - Corporate Culture, Good Government Governance. 


\section{INTRODUCTION}

Regions in Indonesia have a lot of natural resources that can be managed into high-income original areas, which are expected to spend spending wisely so that the quality of service to the community is getting better (Hertati, 2015). On the other hand, regions have income from natural resources with low local revenues must look for alternative revenues so that services to the community are not disrupted (Hertati, 2015). The inequality of potential and wealth of natural resources in each region causes the central government to provide transfer funds to local governments.

The amount of funds transferred from the central government to local governments is not the same depending on the approval of the central government (Hertati, 2016). Some indicators for determining the amount of transfer funds are: area, population and fiscal independence of the regional government. The provision of this transfer fund also aims to improve the performance of the regional government, (Law No. 33 of 2004).

According to Presidential Regulation According to the Indonesian law regulation number 9-year 2015 regarding the second amendment to law number 23 of 2014 concerning regional government concerning Government Institution Performance Accountability System (SAKIP), performance is the output or outcome of activities or programs that have been achieved in connection with the use of budget with quantity and measurable and transparent quality. Output (output) is the goods or services produced to support the achievement of goals, program and policy objectives, and the results (outcomes) are all things that reflect the functioning of the output of activities in one program (Hertati, 2016). According to Jowet and Margaret, (1988), performance is similar to productivity as such as using resources effectively and efficiently to achieve results. Furthermore, Jowet and Margaret, (1988), said that measuring government performance is a systematic assessment of how good service is to the community effectively and efficiently. The term efficient refers to the relationship of the amount of input needed for the amount of output produced. Effectively refers to the impact and quality of services, whether services achieve their goals, and how responsive to community needs. In practice there are still many problems related to the effectiveness of local governments as stated by Nigrum (2016), that SILPA in the North Sumatra Povinsi government is Rp. 536 billion which indicates budget synchronization with the development target.

The same statement was also stated by President Widodo (2016) that there were still funds that settled in the bank in the amount of Rp. 183 trillion that has not been used by the regional government. Furthermore Widodo (2016) said that until the end of 2015 the realization of the Special Allocation Fund (DAK) was only 50\%. The high level of SILPA in the regional government is caused by a lot of problematic development, hampered because SKPD has to deal with law enforcement agencies thereby reducing the effectiveness of regional development, (Kumolo, 2016). On the other hand, financial management in local governments also occurs due to large waste of organizations (Chrisnandi, 2016). The practice of budget waste is also carried out by the central government as recognized by the finance minister.

While Untari (2015) as Chairman of the Working Committee (PANJA) discussing the Audit Results Report (LHP) of the BPK-RI said the financial performance of the East Java Provincial Government in 2014 had decreased. The same thing was said by Azis (2015) that out of 524 regional governments, only 156 were received the WTP opinion and this was a serious problem in terms of governance (good government governance). The results of the study that showed the influence of good government governance on performance were found by Hounaida, (2016) that corporate governance had a positive effect on the performance of Islamic banking. Other research also found that there was a positive and strong relationship between corporate governance and company performance (Gompers and Andrew, 2001; Klapper and Love, 2002).

However, several studies have shown different results, namely research conducted by Aboagye and Otieku, (2010) who conducted research on 30 rural banks in Ghana found that there was no effect of corporate governance on company performance (Fery, 2013). The same results were found by Lamport and Sannase, (2011) that there was no influence between corporate governance and company performance. Governance is the process by which people or organizations make important decisions, determine who is involved in it and how they make decisions, (Graham, et. Al, 2003). While Nadeem, et.al, (2013), states that governance is an effort made to provide guarantees for capital owners to obtain a high return on investment. Indonesia began to implement governance after the economic crisis in mid-1997, where the crisis also occurred in Asian countries which was generally caused by the weak implementation of corporate governance, (Lukviarman, 2016: 25). The Asian Development Bank (ADB, 2000) states that Indonesia is the most severely affected by the crisis and recovers from the crisis the longest.

In troubled economic conditions, the International Monetary Fund (IMF) as a multilateral financial institution offers economic rescue programs to Indonesia and this institution requires the improvement and improvement of governance practices (both public and corporate), (Lukviarman, 2001). The signing of the Letter of Intent (LOI) between the Indonesian government and the IMF is considered a milestone in the start of formal legal governance (government governance and corporate governance) in Indonesia (Fery, 2016), (Lukviarman, 2016: 25). There are problems in good government governance. Chrisnandi's statement (2015), in accordance with the 2015 BPK Semester Examination Results (IHPS) II for the financial statements of provincial, district, cities throughout Indonesia which found that there were non- compliance with statutory provisions on Examination with Specific Purposes (PDTT) on expenditure area which caused state losses of Rp. 336.8 billion. The findings are presented in the table as follows: 
Table 1.1 Number of Losses for Non-compliance with the Provisions of Legislation for the Implementation of Regional Government Expenditures Based on Islands in Indonesia

\begin{tabular}{|c|l|c|}
\hline No & Islands & Amount (Rp) \\
\hline 1 & Sumatera & $152,644.36$ \\
\hline 2 & Jawa dan Bali & $83,029.3$ \\
\hline 3 & Kalimantan & $37,288.62$ \\
\hline 4 & Sulawesi & $34,999.16$ \\
\hline 5 & Papua & $5,873.05$ \\
\hline 6 & Jumlah & $366,834.49$ \\
\hline
\end{tabular}

Source: 2015 IHPS II BPK-RI, data processed

Percentage of the data is presented in the figure as follows:

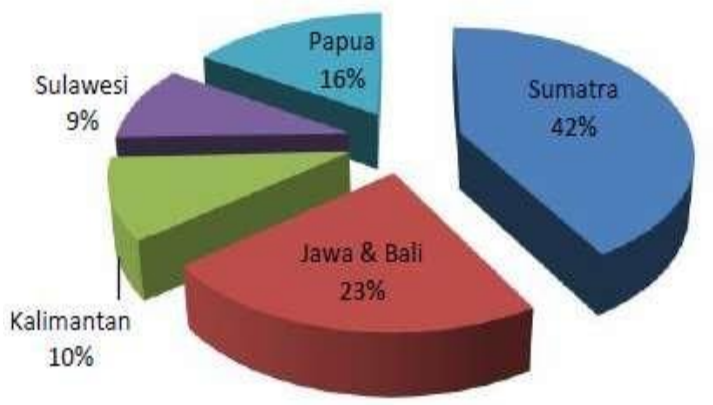

Figure 1.1 Percentage of Loss on Non-compliance with Regulations Legislation on Regional Expenditures Based on Islands in Indonesia Source: 2015 IHPS II BPK-RI, data processed

Based on table 1.2 it appears that the level of financial management accountability in the major islands in Indonesia is still low, this is evidenced by the existence of various irregularities in the implementation of employment and expenditure contracts which led to the high amount of local government losses reaching Rp. 336.8 billion. Of the total losses, the biggest loss is on the island of Sumatra, which is Rp. 152.6 billion or $42 \%$ and on the islands of Java and Bali Rp. 83.03 billion or 23\%. Referring to Chrisnandi's statement (2015) this indicates a problem of good government governance in local governments in Indonesia, especially local governments on the island of Sumatra and the island of Java. Then after further exploration of the regional governments on the islands of Sumatra and Java and Bali the following data were obtained:

The data if presented in the percentage of graphic forms is as follows

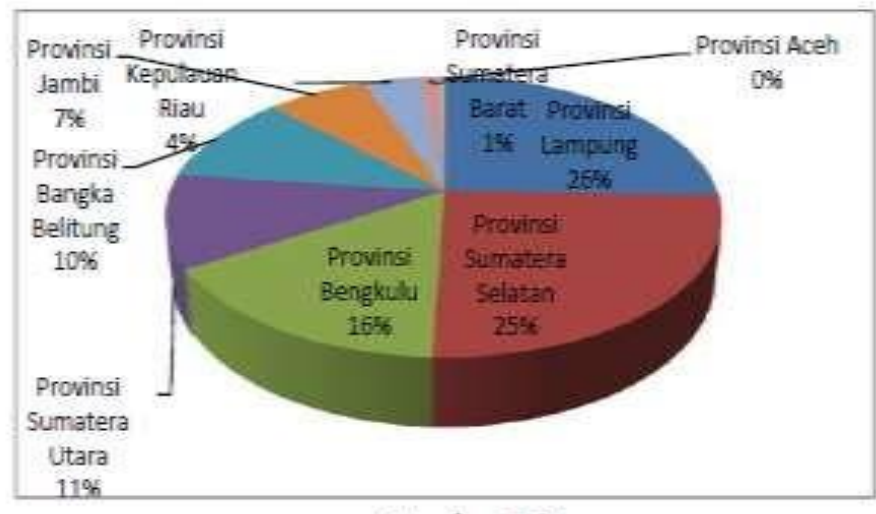

Figure 1.2 Percentage of Loss on Non-compliance with Regulations Legislation on Regional Expenditures Provincial, Regency, City Governments on Sumatra Island

Based on table 1.3 shows that the amount of losses due to problems of good government governance in local governments on the island of Sumatra is the highest occurred in the local government in Lampung Province. Likewise in Figure 1.2 shows the percentage of loss of regional expenditure management in regional government in Lampung Province by $26 \%$. The problem of good government governance is also related to organizational culture, as the results of Mulyani and Arum's research (2016) that effective internal control will affect the achievement of organizational goals. According to COSO, (2013:3) Internal control is a process that is influenced by the board of directors, management, and other personnel, which is designed to provide adequate confidence in achieving goals related to operations, reporting and compliance. While Simon, (1995: 85) said that internal control is a detailed procedure and protection for handling information, transaction processing, and recording. An organization applies and maintains 
internal control, which is then regularly evaluated by internal and external auditors. Organizational culture is very important to ensure good government governance that is used by managers in implementing the Strategy.

The same thing is said by Arens, et. Al (2017: 290) that internal good governance governance consists of policies and procedures designed to provide adequate assurance to management that the goals and objectives of the company can be achieved. These policies and procedures are often called controls, and collectively, they make good government governance. American Institute of Certified Public Accounting, (AICPA, 2014: 1) defines internal control as a process that is influenced by management plans and other personnel, in accordance with corporate governance, and is designed to provide adequate confidence in achieving reporting objectives and reliability.

The problems of good government governance are also related to organizational culture or regional heads. This is in accordance with the statements of Elkeles and Philips, (2006:180) that leaders must be willing to encourage employees (the community) to participate in organizational programs and be more involved in the development and implementation of the organization's programs. Management support is an action taken by all management groups, especially at the top and middle management who support various activities that can affect the effectiveness of the organization, (Philips, et.al, 2001: 79). The same thing was said by Elkeles and Philips, (2006: 261) that organizational culture is the action of the management team, which shows their attitude towards the process of learning and staff development. Furthermore, Elkeles and Philips (2006: 261) say that the support provided by management has a tremendous impact on the success of organizational programs, where one form of organizational culture can be in the form of allocating resources and forms of organizational culture in organizational learning and development. Related to the implementation of good government governance, the form of organizational culture can be seen from three aspects as stated by Santosa (2015), as the Head of Representative of the BPK RI of Bali Province, namely: (a) aspects of commitment, regulation and policy; (b) aspects of human resource management, and (c) aspects of information technology management. In fact, there are still weaknesses in these aspects as happened in the Province of Bali, namely there are no accrual- based Government Accounting Standards implementation plans / strategies, (Santoso, 2015). The same conditions also occur in the government of Bangka Belitung Province, namely the local government has not implemented regional head regulations on accounting policies and regional head regulations regarding the accounting system of local governments, (Subagyo, 2015). Furthermore it was said that the problem of limited human resources in the Regional Work Unit (SKPD) and the Regional Finance Management Work Unit (SKPKD) that understood government accounting was an obstacle for local governments to utilize information technology-based accounting applications. Meanwhile, according to Subowo, (2015) in the Central Java provincial government and seven regencies / cities in Central Java, the existing Human Resources (HR) do not yet have full competency for accrual-based SAP implementation. The results of Hertati, (2016) research provide evidence that top management support is the most important determinant of the implementation of corporate governance. Morgan, (2000) who conducted research on 136 manufacturing companies in America found that corporate culture had a positive effect on performance and accountability.

\section{Organizational Culture.}

Luthan (2006: 45) says that culture, is "the way of life" for a society. Culture can also be defined as a community value system that illustrates that organizational members have one understanding even though they come from different backgrounds (Robbins \& Sanghi, 2007: 520). The concept of culture in a broad and general sense, can be interpreted as a pattern of behavior, beliefs, groups (organizations) and all thoughts that characterize a shared values and tend to survive even though group members have changed (Hertati, 2015). Culture when associated with organizations, will give a different understanding, where organizational culture is a translation of organizational culture that can be interpreted with various meanings. According to Hertati (2016), interpreting organizational culture is a form of assumption that is owned, implicitly accepted by the group and determine how the group feels, think and react to a diverse environment. "The same opinion expressed by Douglas (1985: 27) which states that organizational culture as a shared understanding of basic assumptions, values and beliefs, as well as artifacts and creations that can direct organizational behavior. According to Schein, if the organizational culture runs well and is valid then it can be taught to new members as the right way to perceive, think and feel in relation to other problems at hand.

This definition can be interpreted that: organizational culture is a broad set of values and norms that control the interaction between members of the organization and with people who are outside the organization's environment. Values are general standards and criteria or guiding principles that can be used by people to determine the type of behavior, events, desired and unwanted situations and results. Norms are standards or behavioral styles that are acceptable or typical for a group of people.

Likewise with (Hertati, 2016) defines organizational culture as "values and assumptions that are disseminated in the organization. Based on the expert opinion above, it can be said that organizational culture is a pattern of behavior and thought that characterizes the values that are shared and accepted together in an organization that will be a characteristic that distinguishes between one organization and another organization. Organizational culture can act as a tool to determine the direction of an organization, direct what can be done and what not to do, how to allocate resources and manage organizational resources, and also as a tool to deal with problems and opportunities from internal and external environments (Hertati, 2016).

Supporting values, indicating the values stated explicitly by the organization, are generally the values and norms that have been made by the organization(Susanto 2008: 60). These supporting values are aspirations that will be communicated explicitly to employees, leaders and are expected to influence the behavior of employees directly. However, it will automatically produce the desired behavior because it will require an adjustment process. The values 
played are values and norms that are actually shown and incorporated into employee behavior, in other words the values and norms of the employee. Supporting values and values can be defined as core values and guidelines including diversity, respect and integrity. If employees or employees demonstrate their integrity by carrying out their commitments, then individual behavior is influenced by the value of integrity. But if employees or employees do not carry out their commitments, the value of integrity is only an aspiration that does not affect behavior Malthis and Jackson (2008: 21).

Hertati (2016) states that the function of organizational culture in organizational life is a means to unite the activities of members of an organization consisting of a group of individuals with different backgrounds. According to Robbins \& Sanghi (2007: 725) Culture runs a number of functions within the organization:

1. Culture has a role in setting boundaries; that is to say, culture creates clear distinctions between one organization and another.

2. Culture provides identity for members of the organization.

3. Culture facilitates the emergence of a commitment to something wider than one's individual self-interest.

4. Culture increases the stability of the social system. Culture is a social glue that helps unite the organization by providing the right standards about what employees must say and do.

5. Culture functions as a mechanism for making meaning and controlling mechanisms that guide and shape the attitudes and behavior of employees.

Organizational culture can also be understood from certain dimensions or characteristics that are closely related and interdependent. From the definition of organizational culture that has been stated previously, there does not yet appear to be characteristics that can be measured concretely. The main dimensions or characteristics of organizational culture according to Robbinns and Sanghi (2007:510) include seven characteristics: "innovation and risk taking, attention to detail, outcome orientation, people orientation, team orientation, agesiveness". Furthermore, Robbins \& Coulter (2012: 52) still suggests seven dimensions in organizational culture in a different order from before, namely: "attention to detail, orientation outcomes, people orientation, team orientation, aggressiveness, stability, innovation and risk taking". Robbins \& Judge (2014: 249) also suggests seven characteristics of organizational culture with composition: "innovation and risk taking, attention to detail, outcome orientation, people orientation, team orientation, aggressiveness." Luthans (2008:75) suggests organizational culture characteristics that important is "observed behavioral regularities, norms, dominant values, philosophy, rules, and organizational climate.

\section{Good government governance}

Discussion related to governance became popular in Indonesia after the economic crisis in mid-1997, where the crisis also occurred in Asian countries which was generally caused by the weak implementation of corporate governance, (Lukviarman, 2016: 25). The Asian Development Bank (ADB, 2000) states that Indonesia is the most severely affected by the crisis and recovers from the crisis the longest. In troubled economic conditions, the International Monetary Fund (IMF) as a multilateral financial institution offers economic rescue programs to Indonesia and this institution requires the improvement and improvement of governance practices (both public and corporate), (Lukviarman, 2001). The signing of the Letter of Intent (LOI) between the Indonesian government and the IMF is seen as a milestone in the start of formal legal governance (government governance and corporate governance) reform in Indonesia, (Lukviarman, 2016: 25$)$.

The practice of the process of administering state power is called government governance while the best practice is called good government governance, (Umar, 2006: 30). United Nation

(2007: 2), defines good governance as follows: "Good governance as exercise of authority through political and institutional processes that are transparent and accountable, and encourages public participation" United Nation (2007: 2) defines good government governance as the exercise of authority through transparent and accountable political and institutional processes and community participation. Based on this definition, it can be seen that the main framework of good government governance: Implementation of good government governance. according to Rosario, et.al, (1999)

1. Can be measured through five main elements, namely:

2. Political and bureaucratic accountability,

3. Freedom of association,

4. Efficient objectives and justice,

5. Freedom of information and expression,

6. Efficient public institutions.

\section{The Effect of Organizational Culture on good government governance}

Laudon \& Laudon, 2012: 20 says that organizational culture is a component in organizations that has a strong influence on information systems. Hertati (2015), shows that each organization has a unique culture, which is a set of assumptions, values and ways of doing things, which are accepted by almost all members of the organization (Laudon \& Laudon, 2012: 115). Kendall \& Kendall (2008: 51), emphasize that: organizational culture is an important factor that influences good government governance. Many people feel disappointed because they are doing something positive, and are looking for any effort to encourage the long-standing good government governance (Susanto, 2008: 60). Stair \& Reynolds. (2010: 53), further revealed, "Organizational culture can also have a positive effect on successful development of new information systems" Stair \& Reynolds (2010: 75) added: "The use of information systems to add value to the organization it is strongly influenced by organizational structure, culture, and change. "Opinion Stair \& 
Reynolds (2010: 75) can be interpreted that: good government governance provides added value to organizations with a strong influence of good government governance by organizational structure, culture and change . So it can be said that organizational culture has a strong influence on good government governance (Stair \& Reynolds, 2010: 75).

O'Brien \& Marakas (2010: 17) further states that good government governance is influenced by several factors, one of which is organizational culture. By identifying and understanding the meaning (meaning), norms, and power (power) in the organization is an important consideration in the success of information systems. Hirsch (1994: 88) also states that organizational culture has a very strong influence on the behavior of individuals and organizations as a whole, because good government governance is the main component of the organization, the information system can be influenced substantially by organizational culture. Many good government governance fail, in simple terms, the cause is that good government governance does not match the organizational culture where good government governance is designed.

The opinions of experts above are supported by the results of research conducted by Gray (1998), which shows that organizational culture influences good government governance. This is confirmed by Busco \& Scapens (2011) who prove that public sector organizations that influence organizational governance good governance. In good government governance practices, Bhimani (2003); Etemadi, et al. (2009) and Erserim (2012) find the same results, where organizational culture influences good government governance. Bhimani (2003) conducted research on a Siemens company division, while Etemadi, et al. (2009) found empirical evidence on several multinational companies in Iran, and Erserim (2012) proved it in several industrial companies in Turkey. Based on the description above, it can be concluded that organizational culture has an effect on good government governance.

\section{Methodology}

Quantitative methods were used this study. Data collection using questionnaires. Sampling is based on simple random sampling technique on Fuctional Units in Indonesia SOE's Indonesia. The data were measured using Likert scale fivepoint. Structural Equation Modeling based on component or variance (PLS-SEM) is used for analysis tool. Evaluation of PLS-SEM model includes evaluation of measurement model (outer model) and structural model (inner model). In this study, exogenous and endogenous variables are latent variables. The latent variable measurement model in this research includes: (1) the first order is the dimension measurement model. Dalam mengukur reliabilitas dalam SEM akan digunakan composite reliability measure (ukuran reliabilitas komposit) dan variance extracted measure (ukuran ekstrak varian). Construct reliability dihitung sebagai berikut :

$$
\mathrm{CR}=\frac{\left(\sum \text { std.loading }\right)^{2}}{\left(\sum \text { std. loading }\right)^{2}+\sum \mathrm{ej}}
$$

Where std loading (standardized loadings) can be obtained directly from the LISREL-8.7 and ej program output is a measurement error for each indicator or variable observed. Extract variants reflect the total number of variants in the indicators (observed variables) explained by latent variables. The size of the extract variant (extracted variant) can be calculated as follows):

$$
\text { Variance Extracted }=\frac{\sum s t d . \text { loading }^{2}}{\sum s t d . \text { loading }^{2}+\sum e_{j}}
$$

Hypothesis Organizational culture influences good government governance:

$\mathrm{H} 0: \gamma 1.1 \geq 0: \mathrm{H} 0: .11 .1 \geq 0$ : There is an influence of organizational conference on good government govemance.

$\mathrm{H} 1: \gamma 1.1<0$ : There is an influence of organizational

\section{MEASUREMENT MODEL}

Hair, Jr. et, al, (2014) based on the framework developed in this study, for the purpose of testing the hypothesis is made the structure of the analysis of the overall research variable which is a combination of the measurement model and structural model that describes the causality relationship between exogenous variables and endogenis variables. states that to build an indicator precisely the formative combination of indicators. If it is reflective and if a combination. Indicators represent consequences that reflect or cause constructs. if there are consequences and if formative causes. If the assessment of changes in nature, all items will change in the same way (assuming they are both coded), if it is reflective and if not formative.

\subsection{Results of Evaluation of Indicator Validity}

According to Bollen (1989) the validity of each reflective indicator is seen from the significance of loading factors. As explained earlier, in this study the variables of environmental uncertainty and the quality of the testing of each loading, it is done by comparing the p-values with a significance level. Refuse Ho, if the p-value is smaller than 0.05 . The summary of the results of testing the validity of the indicators is presented in table 1.1., as follows:

1. Culture has a role in setting boundaries; that is to say, culture creates clear distinctions between one organization and another.

2. Culture provides identity for members of the organization.

3. Culture facilitates the emergence of a commitment to something wider than one's individual interests.

4. Culture increases the stability of the social system. Culture is a social glue that helps unite the organization by providing the right tandards about what employees must say and do. 
5. Culture functions as a mechanism for making meaning and controlling mechanisms that guide and shape the attitudes and behavior of employees.

Table 1.1. Evaluation Results of Dimensional Relevance Measurement

\begin{tabular}{|c|c|c|c|c|c|c|c|}
\hline Latent & Dimension & Weight & $\begin{array}{l}\text { Default } \\
\text { error }\end{array}$ & Value- $z$ & Nilai- $\mathbf{p}$ & Sig & Relevant \\
\hline \multirow{5}{*}{$\begin{array}{l}\text { Organization } \\
\text { al culture }\end{array}$} & Culture has a role & 0,44 & 0,013 & 33,94 & 0,000 & Sig & Relevant \\
\hline & Culture gives identity & 0,46 & 0,014 & 33,86 & 0,000 & Sig & Relevant \\
\hline & $\begin{array}{l}\text { Culture facilitates } \\
\text { commitment }\end{array}$ & 0,45 & 0,013 & 34,25 & 0,000 & Sig & Relevant \\
\hline & $\begin{array}{l}\text { Culture increases social } \\
\text { stability }\end{array}$ & 0,43 & 0,013 & 33,44 & 0,000 & Sig & Relevant \\
\hline & $\begin{array}{l}\text { Culture functions as a } \\
\text { maker of meaning }\end{array}$ & 0,45 & 0,015 & 30,25 & 0,000 & Sig & Relevant \\
\hline $\begin{array}{l}\text { good } \\
\text { government }\end{array}$ & $\begin{array}{l}\text { Political and bureaucratic } \\
\text { accountability }\end{array}$ & 0,40 & 0,017 & 22,67 & 0,000 & Sig & Relevant \\
\hline \multirow[t]{4}{*}{ governance } & Freedom of association & 0,45 & 0,017 & 26,32 & 0,000 & Sig & Relevant \\
\hline & $\begin{array}{l}\text { Objectives and justice } \\
\text { efficient }\end{array}$ & 0,46 & 0,011 & 39,99 & 0,000 & Sig & Relevant \\
\hline & $\begin{array}{l}\text { Freedom of information } \\
\text { And expression }\end{array}$ & 0,46 & 0,013 & 35,21 & 0,000 & Sig & Relevant \\
\hline & $\begin{array}{l}\text { Public institutions } \\
\text { efficient }\end{array}$ & 0,47 & 0,014 & 34,69 & 0,000 & Sig & Relevant \\
\hline
\end{tabular}

Source: results of calculation of the score component with the R program

Evaluation of structural models is intended to determine the effect of organizational culture (X1), on good governance governance $(\mathrm{Y})$ results of data processing and model estimation using LISREL software as follows:

Tabel 1.2 Parameter Model Struktural

\begin{tabular}{|c|c|c|c|c|c|c|c|c|}
\hline Consequence & Mediator & Cause & $\begin{array}{l}\text { Standard } \\
\text { estimates }\end{array}$ & Estimates & $\begin{array}{l}\text { Default } \\
\text { error }\end{array}$ & $\begin{array}{l}\text { Value- } \\
\mathrm{z}\end{array}$ & $\begin{array}{l}\text { Value- } \\
\mathrm{p}\end{array}$ & R2 \\
\hline $\mathrm{OC}$ & GGG & GGG & 1,00 & 0,912 & 0,03 & 32,70 & 0,000 & Sig \\
\hline
\end{tabular}

Source: Data Processed 2019

Based on information obtained from table 4.5, the interpretation of the results of evaluation of structural equation models can be explained that the magnitude of the influence of organizational culture on good government governance is 0.32 can be interpreted every increase in organizational culture 1 standard deviation resulted in a decrease in good government governance an average of 0.32 standard deviation assuming other variables are constant.

\section{Test Reliability}

Testing the reliability of research instruments carried out internally. According to Sugiono (2012) reliability tests were conducted to determine whether the measuring instruments that had been designed in the form of a questionnaire were reliable. Sugiyono, (2012) Instruments that are reliable or reliable, will produce reliable data too. Reliability testing was carried out using Cronbach's Alpha which measures consistency between items in the questionnaire. The general criteria used are: an instrument that is reliable internally if the Cronbach's Alpha coefficient is $>0.60$. Reliability testing is done using SPSS software ver. 20 for Window. The following is a summary of the calculation results for testing the validity of the research instruments for each variable.

\section{Results Of The Path Structure Of Sub Structure Two}

The hypothesis proposed is that there is an influence of organizational culture on good government governance. The results of statistical tests show that organizational culture has a positive and significant influence on good government governance. In Indonesia the hypothesis can be confirmed by data.

\section{Conclusion.}

Organizational culture influences good government governance. Good and bad organizational culture will affect good government governance. good government governance Political and bureaucratic accountability, freedom of association, efficient objective and justice, freedom of information and expression, efficient public institutions Culture has a role in setting boundaries; that is to say, culture creates clear distinctions between one organization and another. Culture provides identity for members of the organization. Culture makes it easier to arise commitment to something wider than one's individual self-interest. Culture increases the stability of the social system. Culture is a social glue that helps unite the organization by providing the right standards about what employees must say and do. Culture functions as a mechanism for making meaning and controlling mechanisms that guide and shape the attitudes and behavior of employees. In accordance with the theory and previous research. Furthermore, the results of this study may be examined by other researchers by adding variables, dimensions or indicators used. 


\section{Acknowledgment}

This research was supported by Directorate General of Higher Education, Ministry of Research, Technology and Higher Education Republic of Indonesia, Fuctional Units in Indonesia SOE's, We thank our colleagues from SOE's Indonesia and who provided insight and expertise that greatly assisted the research, although they may not agree with all of the interpretations/conclusions of this paper.

\section{References}

[1].Aboagye, Anthony Q. and Otieku, James. 2010. Are Ghanaian MFIs' performance associated with corporate governance?. The international journal of business in society, Vol. 10 Iss 3 pp. $307-320$

[2].Azis, Harry Azhar. 2014. 7 Financial Issues that must be addressed by the Government. Through: http://www.suara.com/bisnis/2014/12/03/053 800/7-problem

[3].American Institute of CPAa (AICPA). 2014. The Importance financial-that-must-be addressed-government Safeguarding Plan Assets

[4].Arens, A. Alvin., Randal.J.Elder., Mark, S. Beasley. 2017. Auditing and Assurance Service. Prentice Hall

[5].Chrisnandi, Yudi. 2015. Bureaucracy Must Be Efficient and Transparent.Via: http://jabarprov.go.id/index.php/news/11025/ YUDI_Birokrasi_Harus_Efis ien_dan_Transparan Chrisnandi, Yudi. 2016. Minister Yuddy Ordered to Trim Local Government Organizations that Are Not Important. Through: http://www.jpnn.com/read/2016/04/29/39591 7/Minister-Yuddy ordered- Trim-bOrganisb- Pemda-byang-NotImportant-

[6].COSO. 2013. Internal Control Integrated Framework. American Institute of Certified Public Accountant

[7].Douglas, Mary. 1985. Measuring Culture: A Paradigm for the Analysis of Social Organization. New York: Columbia University Press

[8].Elkeles,Tamar \& Philips,J.Jack. 2006. The chief learning officer Driving Value Within a Changing Organization Through Learning and Development. Published by Elsevier Inc Jowet, Paul \& Rtohwel, Margaret. 1988.

[9].Peformance Indicators in The Public Sector. The Macmillan Press LTD

[10]. Kumolo, Tjahjo. 2015. Application of Accrual Accounting Systems in Regions Has Not Been Optimal. Through http://www.kemendagri.go.id/news/2015/11/24/penerapan-sistemakuntansi-accrual-in- area-not-optimal

[11]. Klapper, Leora F. \& Love, Inessa. (2002). Corporate governance, investor protection, and performance in emerging markets, World Bank Policy Research Working Paper Series 2818

[12]. Lamport M J, Latona M N, Seetanah B and Sannassee R V. 2011. Relationship between Corporate Governance and Firm Performance: Evidence from a sample of Top 100 Mauritian Companies. Proceeding, Cambridge Business and Economic Conference. ISBN: 9780974211428

[13]. Lukviarman, Niki. 2001. Key Characteristic of corporate governance: The Case in Indonesia. Working Paper, Graduate Shool of Buiness, Certin University of Technology

[14]. Luthan, Fred. 2006. Organizational Behavior, 10th edition, McGraw-Hill International Ed, Singapore.

[15]. Lukviarman, Niki. 2016. Corporate Governance, Towards Strengthening Concepts and Implementation in Indonesia. The Age of Adicitra IntermediaGraham, John., Bruce, Amons,., Plumptre, Tim. 2003. Principle for Good Governance in the 21st Century. Institute of Governance

[16]. Laudon, K.C. \& Laudon, J.P. 2008. Management Information Systems. 10th Edition. Prentice-Hall. Inc. New Jersey

[17]. Gompers, Paul A, and Andrew Metrick. (2001), Institutional Investors and Equity Prices. Quarterly Journal of Economics, CXIV, 229-260.

[18]. Hertati. \& Zarkasyi2 2015. Competence of Human Resources, The Benefits of Information Technology on Value of Financial Reporting in Indonesia. Research Journal of Finance and Accounting www.iiste.org.ISSN 2222-1697 (Paper) ISSN 2222-2847 (Online) Vol.6, No.8, 2015

[19]. Hertati.2015. Impact of uncertainty of environment and organizational cultural on accounting information system management and implications for managerial performance proposing a conceptual framework. International Journal of Economics, Commerce and Management United Kingdom Vol. III, Issue 12, December 2015 Licensed under Creative Common Page 455 http://ijecm.co.uk/ ISSN 23480386

[20]. Hertati. 2015. Total Quality Management As Technics On Strategic Management Accounting. International Journal of Recent Advances in Multidisciplinary Research Vol. 02, Issue 11, pp.0942-0949, November, 2015

[21]. Hertati, 2015. Internal Control And Ethics Of Quality Management System Accounting Information And Implications On The Quality Of Accounting Information Management: Proposing A Research Framework. International Journal of Economics, Commerce and Management United Kingdom Vol. III, Issue 6, June 2015 Licensed under Creative Common Page 902 http://ijecm.co.uk/ ISSN 23480386

[22]. Hertati. 2016. Just In Time, Value Chain, Total Quality Management, Part Of Technical Strategic Management Accounting. International Journal Of Scientific \& Technology Research Volume 5, Issue 04, April 2016 Issn $2277-8616$

[23]. Hertati \& Sumantri 2016. Just In Time, Value Chain, Total Quality Management, Part Of Technical Strategic Management Accounting.International Journal Of Scientific \& Technology Research Volume 5, Issue 04, April 2016 Issn 2277-8616.

[24]. Hair.Jr.Joseph F; Hult,G.Thomas; Ringle,M.Christine; Sarstedt,Marko. 2014. A Prime Partial Least Squares Structural Equation Modeling (PLS-SEM). SAGE Publication Ltd

[25]. Hounaida Mersni Hakim Ben Othman. 2016. The impact of corporate governance mechanisms on earnings 
management in Islamic banks in the Middle East region. Journal of Islamic Accounting and Business Research, Vol. 7 Iss 4

[26]. Fery. 2013. Analysis of Regional Tax Contributions to Regional Original Revenue in Musi Banyuasin Regency. Date of issue 2013/5 Jenius PalmcomTech Journal Palembang. Volume 1 Issue Volume 1 No.1 Palmcomtech Publisher Palembang

[27]. Fery. 2016. Potencial Increase in Revenue Collection BPHTB Tax District Musi Banyuasin. Tanggal terbit.2016/1 Jurnal. European Journal of Accounting, Auditing and Finance Research (EJAAFR) Jilid 1 Terbitan ISSN :20534086(paper) 2053-4094(online) Penerbit EJAAFR, Inggris

[28]. Malthis, Robert L and Jackson, John H. 2008. Human Resources Management $12^{\text {th }}$ edition. Thomson South Western McLeod, R. \& Schell, G. 2007. Management Information Systems. 9thEdition. Prentice- Hall. Inc. New Jersey Mulyani,Sri and Arum, Enggar Diah Puspa.2016. The influence of manager competency and internal control effectiveness toward accounting information quality. I J A B E R, Vol. 14, No. 1, (2016): 181-190

[29]. Morgan, Swink. 2000. Tehnological innovativeness as a moderator new product desaign integration and top management support. Journal Prod Innovation Management. 7. Pp.208-220

[30]. Nadeem, Ahmed Sheikh; Zongjun, Wang and Shoaib, Khan. 2013. The impact of internal attributes of corporate governance on firm performance. International Journal of Commerce and Management Vol. 23 No. 1, 2013. pp. $38-55$

[31]. Ningrum, Rurita. 2016. Silpa Rp536 M Proves Poor Provincial Government Performance. Through: http://www.koran- sindo.com/news.php?r=5\&n=86\&date=201 6- 08-04. Accessed September 1, 2016

[32]. O’Brien, James A., and Marakas, George M. 2010. Management Information Systems. Fifteenth Edition. New York: McGraw-Hill/ Irwin

[33]. Untari,Sri. 2015. East Java Provincial Government Internal Control System CPC is Weak. Via: http://news.detik.com/berita- jawa-timur/2955206/bpk-nilaisistem- internal theprovincial government

[34]. Philips, Jack.J.1999. Accountability in Human Resource Management. Gulf Publishing Company. Houston, TX

[35]. Robbins, Stephen, P., and A Judge Timothy. 2008. Organizational behavior (Organizational nBehavior) 12th edition Salemba four.

[36]. Robbins, Stephen, P., and A Judge Timothy. 2012. Essentials of Organizational Behavior. 12th edition. Pearson Education, Inc.

[37]. Santoso, Dori. 2015. Regents / Mayors are asked to Immediately Follow Up on BPK Findings.

[38]. http://www.rri.co.id/madiun/post/berita/216 130/daerah/bupatiwalikota_diminta_segera_t follow up_discussion_bpk.html Accessed 11 Oct 2016, Time 16.24

[39]. Subagyo.2015. Provincial Government B. Commitments to Apply Accrual Based Accounting in the Region. Accessed through: http://babelprov.go.id/content/pemprov committed-accounting-accounting-based- accrual-inregion. May 25, 2016.

[40]. Subowo, Hery.2015. Local Government HR Has Not Complied with the Arrangement of Accrual-Based SAP. Accessed through: http://m.semarangpos.com/2015/11/07/lapo ran-keuangan-pemerintahsdm- Pemerintah- daerahbelum-sempiti-sus-sus-sus-sap- based-accrual-659129. May 14, 2016 Susanto. 2008. Accounting Information Systems. 